\title{
PENGUNAAN RADIO RIG SEBAGAI GENERATOR FREKUENSI CARRIER UNTUK KOMUNIKASI DATA DIGITAL JARAK JAUH
}

\author{
Satria Gunawan Zain ${ }^{1}$, Abd. Rahman Patta ${ }^{2}$, Muliaty Yantahin ${ }^{3}$ \\ ${ }^{1}$ Teknik Komputer, Universitas Negeri Makaasar \\ sg.zain@gmail.com \\ ${ }^{2}$ Teknik Komputer, Universitas Negeri Makaasar \\ abdrahman@gmail.com \\ ${ }^{3}$ Pendidikan Teknik Elektro, Universitas Negeri Makaasar \\ dkfioc.yantahin@unm.ac.id
}

\begin{abstract}
ABSTRAK
Tujuan dari penelitian ini adalah untuk menguji efektifitas penggunaan radio RIG sebagai Generator Frekuensi Carrier untuk komunikasi jarak jauh. Jenis penelitian ini adalah penelitian terapan dengan model prototyping. Dengan tahapan kajian pustaka, peracangan sistem dan prototype, simulasi model atau prototype kemudian perancangan prototype. Perangkat komunikasi yang dibangun ini dapat digunakan dengan spesifikasi jarak perangkat komunikasi atau jarak antar kapal nelayan tidak lebih dari $10 \mathrm{~km}$. Perangkat komunikasi data ini memiliki kecepatan pengiriman data maksimal sebesar 2400 bit per detik. Perangkat ini dapat digunakan untuk mengirimkan informasi terkait dengan aktifitas kapal nelayan seperti posisi kapal nelayan, distribusi titik tangkap ikan nelayan dan informasi penting yang lainnya seperti evakuasi kecelakaan laut dan monitoring pelanggaran batas wilayah dari nelayan Indonesia.
\end{abstract}

Kata Kunci: Modem Radio, Boudrate, Kapal Nelayan.

\section{USE OF RADIO RIG AS CARRIER FREQUENCY GENERATOR FOR REMOTE DIGITAL DATA COMMUNICATION}

\begin{abstract}
The purpose of this study was to test the effectiveness of using RIG radio as a Carrier Frequency Generator for long distance communication. This type of research is applied research with a prototyping model. With the stages of literature review, system design and prototype, model simulation or prototype then prototype design. This communication device that is built can be used with specifications for the distance of the communication device or the distance between fishing boats is not more than $10 \mathrm{~km}$. This data communication device has a maximum data transmission speed of 2400 bits per second. This device can be used to send information related to fishing vessel activities such as the position of fishing boats, distribution of fishing points for fishermen and other important information such as evacuation of marine accidents and monitoring of territorial boundary violations from Indonesian fishermen.
\end{abstract}

Keyword: Radio Modem, Boudrate, Fishing Boat. 


\section{PENDAHULUAN}

Potensi sumber daya kelautan Indonesia sangat besar [1] dan diharapkan dapat meningkatkan kesejahteraan nelayan dan memberi peningkatan devisa negara. Nelayan tradisional yang memanfaatkan peta titik tangkapan ikan dapat efektif menangkap ikan untuk daerah yang mudah dijangkau dalam perjalanan tidak kurang dari sehari. Namun untuk menjangkau titik tangkapan yang lebih jauh lagi maka peta titik tangkapan ikan tidak lagi efektif memberikan informasi yang akurat karena data titik tangkap ikan berubah setiap harinya. Peta titik tangkapan ikan sulit untuk didistribusikan ke nelayan karena kurangnya sarana telekomunikasi di laut lepas. Pengadaan sarana komunikasi untuk distribusi titik tangkapan ikan sangat dibutuhkan nelayan untuk mendapatkan informasi mengenai titik tangkapan ikan.

Jaringan ADHOC dapat menjadi solusi dalam membangun komunikasi antara ground statiun atau server di darat dan kapal nelayan di laut lepas. Frekuensi yang digunakan adalah low frekuensi atau high frekuensi dengan jangkauan propagasi dapat mencapai hingga seratus kilometer [2] . Kapal yang dilengkapi dengan teknologi ini dapat membetuk simpul-simpul jaringan komunikasi hingga ke gound statiun. Interkoneksi antara satu kapal dengan kapal yang lain di laut lepas berdampak pada kemudahan dalam ditribusi peta digital titik tangkapan ikan. Penerapan teknologi ini dapat menekan biaya operasional dalam menangkap ikan. Disisi lain teknologi jaringan komunikasi AD-HOC dan teknologi sonar yang dipasang di kapal nelayan dapat menjadi sarana dalam merekam sample jumlah ikan dibeberapa titik di wilayah Indonesia secara bersamaan sehingga memungkinkan untuk dapat menghitung jumlah ikan diperairan Indonesia.

Untuk membangun jaringan AD-HOC dalam menunjang komunikasi data antara kapal nelayan dibutuhkan perangkat modem radio yang mempunyai kemampuan mengirimkan data dengan jangauan hingga ratusan kilometer. Modem Radio ini menggabungkan data digital dengan frekuensi pembawa dengan bentuk modulasi berupa Diferentian phase shift keying [3]. Penggunaan radio Handy Talky dalam komunikasi dua arah telah banyak digunakan untuk komunikasi dua arah dengan jarak yang dapat puluhan hingga ratusan kilometer

\section{METODE PENELITIAN}

Penelitian tentang penentuan tangkapan ikan telah banyak dilakukan seperti [4] yang menggunakan paramaeter oseanografi dan menggunakan citra satelit TERRA MODIS di daerah perairan Probolinggo dengan koordinat lintang $7^{\circ} 20^{\prime} 28.41^{\prime \prime S}$ sampai $7^{\circ} 41^{\prime} 6.74 " \mathrm{~S}$ dan bujur $113^{\circ} 6^{\prime} 29.97 " \mathrm{E}$ sampai $113^{\circ} 34^{\prime} 45.27$ "E. [5] memanfaatkan data citra modis untuk memperbaiki hasil deteksi daerah tangkapan ikan pantai timur barat Sumatra Utara. [6] memanfaatkan sebaran suhu permukaan untuk memprediksi daerah penangkapan ikan cakalang diperairan laut banda. Penelitian dan pemanfaatkan teknologi prediksi posisi tangkapan ikan bahkan telah dimanfaatkan pemerintah melalui KKP yang merilis posisi tangkapan ikan setiap harinya.

Informasi ini tentunya sangat berguna bagai nelayan untuk digunakan dalam mencari ikan. Namun beberapa kasus nelayan masih kurang optimal dalam memanfaatkan informasi tersebut seperti pada operasi penangkapan ikan hingga berminggu-minggu sehingga informasi titik tangkapan ikan yang diperoleh tidak uptudate. Disisi lain teknologi komunikasi data area laut lepas sangat terbatas sehingga menyulitkan dalam mengakses informasi titik tangkapan ikan terkini. Dibutuhkan teknologi yang dapat memungkinakan terjalin introkenksi kapal dalam laut lepas.

Jaringan ad Hoc adalah kumpulan node nirkabel yang bergerak secara dinamis membentuk jaringan sementara tanpa menggunakan infrastruk administrasi terpusat [7]. Dengan jaringan $A D-H O C$ ini maka router yang sifatnya mobile akan secara adaptif dan mengorganisir dirinya sendiri sehingga topologi jaringan dapat berubah secara cepat.

Jaringan ad hoc ini memungkian untuk komunikasi data dari darat sebagai stasiun pusat informasi dan monitoring dengan kapal yang berada ratusan kilomoter jaraknya. Harga yang murah dan jangkauan yang jauh menjadikan wireless ADHOC menjadi pilihan dalam komunikasi data antar kapal. Wireless ADHOC dapat menggunakan frekuensi VHF (Very high Frekeunsi) yang memiliki propagasi yang baik. [7] menggunakan kanal frekuensi VHF dengan daya pacar $5 \mathrm{~W}$ dan gain antena $8 \mathrm{dBi}$ dapat mencapai jangkauan jarak $22 \mathrm{~km}$. Penggunaan kanal frekuensi VHF untuk jaringan $A D-H O C$ sangat efektif digunakan dilaut hal ini dapat dilihat dari hasil percobaan yang dilakukan oleh [7] yang masih menerima data karakter yang utuh tanpa kesalahan saat diuji cobakan dilaut hingga jarak $11 \mathrm{~km}$ dengan level daya terima sebesar $-102 \mathrm{dBm}$. Berbeda dengan penggunaan frekeunsi yang sama untuk jaraingan $A D$ $H O C$ dihasilkan kesalahan pengiriman karakter pada jarak $4 \mathrm{~km}$ dengan level daya terima sebesar $-75 \mathrm{dBm}$. 
Tujuan dari penelitian ini adalah untuk menghasilkan prototipe modem radio yang dapat mendukung komunikasi data peta digital titik tangkap ikan dari kapal ke ground station. Prototipe modem radio yang menjadi tujuan dari penelitian ini berupa perangkat pemodulasi dan demodulasi dengan tipe Frekuensi Shift Keying (FSK) yang akan ditumpakan ke perangkat komunikasi dari handy talky. Unjuk kerja dari prototipe yang dibuat dianalisis untuk mendapatkan gambar spesifikasi jaringan ADHOC kapal nelayan.

Jenis penelitian ini adalah penelitian terapan dengan model prototyping. Dengan tahapan kajian pustaka, peracangan sistem dan prototype, simulasi model atau prototype kemudian perancangan prototipe. Penelitian ini dilakukan di laboratoriun elektro dengan jangka waktu penerlitian kurang lebih enam bulan.

Peubah dari peneltian ini adalah kecepatan pengiriman data, jangkauan dari pengiriman data. Kecepatn pengiriman data diukur dengan mengamati kesempurnaan pengiriman data untuk berbagai kecepatan yang diberi satuan bit per second (bps). Variabel kedua berupa jangkauan pengiriman data. Variabel ini diamati dengan mengatur jarak pengirim dan penerima kemudian mengamati efektifitas pengiriman dan penerimaan data.

Pengumpulan data dilakukan dengan melakukan pengukuran terhadap kecepatan pengiriman data menggunakan osiloskop. Untuk pengambilan data jarak dilakukan dilapangan dengan memindahkan posisi penerima kemudian memonitok kesatabilan data yang diterima. Untuk pengambilan data kuat sinyal terima dilakukan dengan pengukuran penerimaan radio menggunakan instrumen spektrum analyzer.

Data dianalisis mengunakan teknik diskripsi. Seluruh data yang dikumpulkan diolah secara grafis dan tabel kemudian diinterpretasikan sehingga menghasilkan deskripsi tentang kemampuan dari prototip modem radio yang dibuat. Hasil dari analisis data ini akan didapatkan gambaran tentang berapa kuat sinyal minimal yang untuk mendapatkan data penerimaan telemetry yang stabil tanpa kesalahandata. Yang kedua dihasilkan hubungan antara boudrate maksimal dan jarak efektif pengiriman data serta besaran kuat sinyal yang diterima.

\section{HASIL DAN PEMBAHASAN}

Panelitian ini menghasilkan prototipe komunikasi data wireless yang memanfaatkan modulasi FSK dalam pengiriman dan penerimaan informasi digital. Modem FSK ini dibangun menggunakan sebuah ic TCM3105 dengan boudrate maksimal sebesar 2400 bps.

Prototipe komunikasi radio menggunakan IC TCM diuji secara fungsional. Pengujian pertama yaitu pengujian modulasi fsk yang dihasilkan dari modem FSK TCM 3105. Pengujian berikutnya yaitu pengukuran pengiriman data dari satu perangkat dengan perangkat lainnya. Setiap perangkat terdiri dari Radio HT dan sebuah modem FSK 3105. Gambar 1 menunjukkan model pengujian pengiriman data.
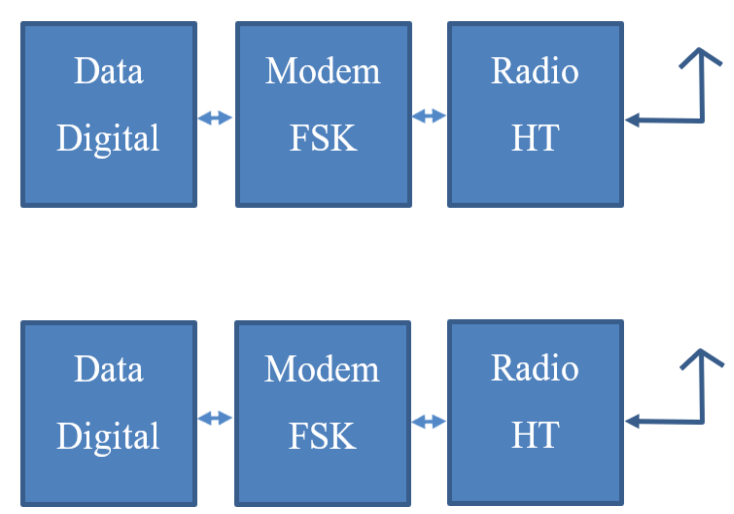

Gambar 1. Model Pengujian Pengiriman Data

Pengiriman data karakter "A" dikirimkan dari pemancar dan diuji penerimaannya di penerima. Setiap bagian diukur untuk menunjukkan bentuk sinyalnya. Gambar 1 menunjukkan data sinyal digital yang dikirimkan. Data yang dikirimkan berupa data digital yang sumbernya dapat berupa data koordiat posisi GPS ataupun data informasi yang lainnya. Gambar 2 merupakan data digital dari karakter "A" dimana kode asci dari kode tersebut adalah 97 atau dalam format binernya adalah 1100001. Angka 1 direpresentasikan dengan tegangan 5 volt dan data 0 direpresentasikan dengan tegangan 0 volt.

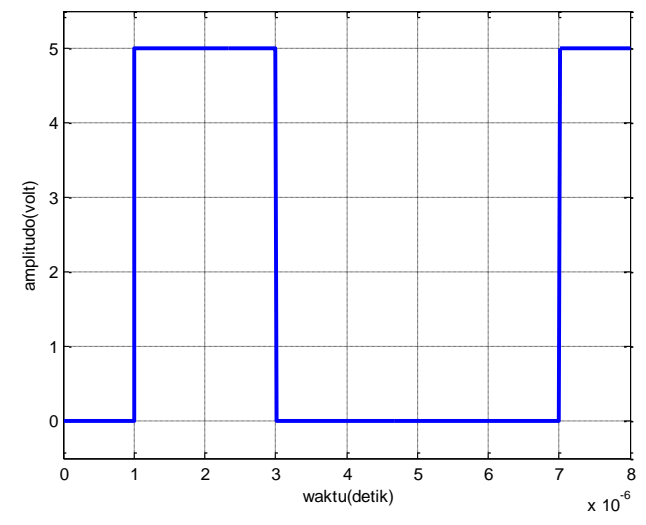

Gambar 2. Sinyal Digital Karakter "A"

Data digital ini dimodulasi menggunakan modulasi frekuensi Shift Keying (FSK). Hasil modulasi FSK dapat dilihat seperti pada Gambar 3. Frekuensi tinggi merepresentasikan data 1 dan frekuensi rendah merepresentasikan data 0. Sinyal 
modulasi FSK ini dikirimkan melalui perangkat radio $\mathrm{HT}$.

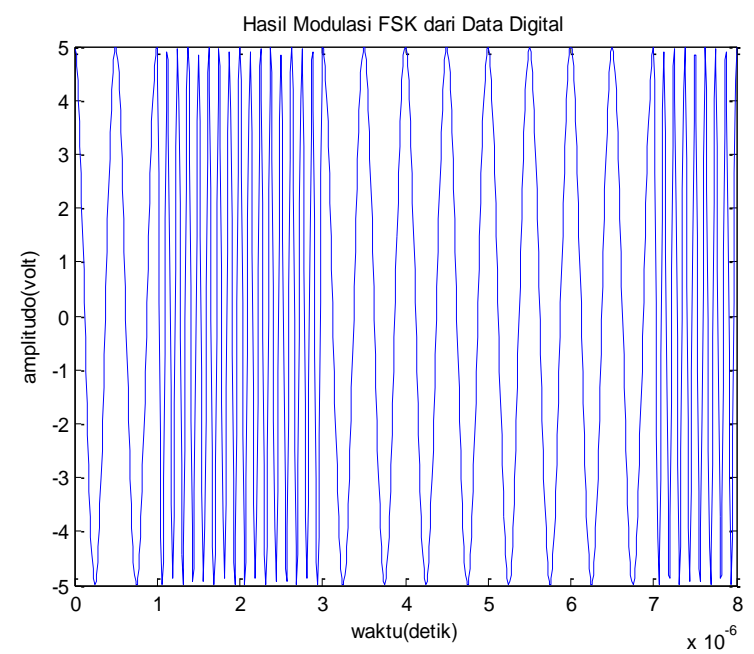

Gambar 3. Modulasi FSK

Radio HT penerima memodulasi sinyal tersebut menjadi sinyal digital yang mengandung informasi. Sinyal atau data digital yang dikirimkan sama dengan data atau sinyal digital yang didemodulasikan.

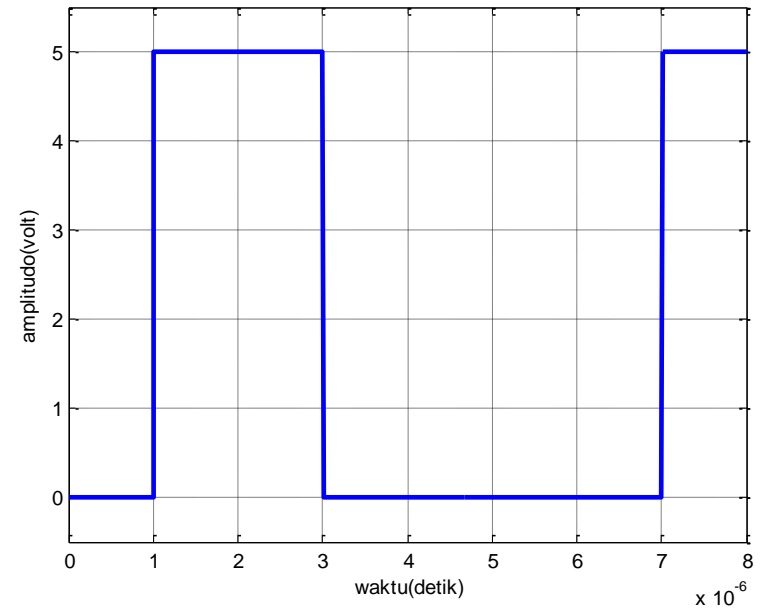

Gambar 4. Sinyal Demodulasi FSK

Tabel 1 menunjukkan pengujian jarak. Pengujian ini dilakukan untuk mengetahui seberapa jauh jarak yang masih efektif komunikasi data menggunakan prototipe ini. Posisi pemancar dan penerima divariasikan. Mulai dari jarak 100 meter kemudian dikirimkan dara digital berupa teks "Uji Coba". Pada bagian receiver data dipantau apakah data tersebut dapat diterima dengan baik. Tiap terjadi kesalah pengiriman data maka dituliskan dalam kolom kesalahan dan kolom tingkat keberhasilan. Terlihat pada Tabel 1. Bahwa jarak efektif yang masih dapat menerima data dengan baik hingga pada $10 \mathrm{~km}$. diatas jarak tersebut maka terjadi kesalahn pengukuran atau tingkat keberhasilannya dibawah $100 \%$.
Secara fungsional prototipe yang dibuat telah memenuhi syarat sebagai perangkat komunikasi data digital. Data digital yang dikirimkan lewat gelombang elektromagnetik melalui perantara perangkat radio HT dapat diterima dan dipulihkan kembali menjadi data digital asli. Langkah selanjutnya untuk mengukur efektifitas penggunaan modulasi FSK untuk perangkat radio ADHOC adalah dengan menguji jarak dan kemampuan dari prototipe yang dapat digunakan untuk menerima data.

\begin{tabular}{|c|c|c|c|c|c|}
\hline No & $\begin{array}{l}\text { Jarak } \\
\text { TX-TX } \\
\text { (meter) } \\
\end{array}$ & $\begin{array}{l}\text { Data } \\
\text { yang } \\
\text { dikirim } \\
\end{array}$ & $\begin{array}{l}\text { Data Yang } \\
\text { diterima }\end{array}$ & Kelasahan & $\begin{array}{l}\text { Tingkat } \\
\text { Keberhasilan } \\
(\%) \\
\end{array}$ \\
\hline 1. & 100 & $\begin{array}{l}\text { "Uji } \\
\text { coba" }\end{array}$ & "Uji coba" & 0 & 100 \\
\hline 2. & 500 & $\begin{array}{l}\text { "Uji } \\
\text { coba" }\end{array}$ & "Uji coba" & 0 & 100 \\
\hline 3. & 1000 & $\begin{array}{l}\text { "Uji } \\
\text { coba" }\end{array}$ & "Uji coba" & 0 & 100 \\
\hline 4. & 2000 & $\begin{array}{l}\text { "Uji } \\
\text { coba" }\end{array}$ & "Uji coba" & 0 & 100 \\
\hline 5. & 3000 & $\begin{array}{l}\text { "Uji } \\
\text { coba" }\end{array}$ & "Uji coba" & 0 & 100 \\
\hline 6. & 4000 & $\begin{array}{l}\text { "Uji } \\
\text { coba" }\end{array}$ & "Uji coba" & 0 & 100 \\
\hline 7. & 5000 & $\begin{array}{l}\text { "Uji } \\
\text { coba" }\end{array}$ & "Uji coba" & 0 & 100 \\
\hline 8. & 10000 & $\begin{array}{l}\text { "Uji } \\
\text { coba" }\end{array}$ & "Uji coba" & 0 & 100 \\
\hline 9 & 15000 & $\begin{array}{l}\text { "Uji } \\
\text { coba" }\end{array}$ & "Ujix)oba" & 2 & 75 \\
\hline 10. & 20000 & $\begin{array}{l}\text { "Uji } \\
\text { coba" }\end{array}$ & $\begin{array}{l}\text { "Uji } \\
\& c x b x "\end{array}$ & 5 & 62,5 \\
\hline 11. & 25000 & $\begin{array}{l}\text { "Uji } \\
\text { coba" }\end{array}$ & “" & 8 & 0 \\
\hline
\end{tabular}

Pengujian selanjutnya yaiut pengujian kecepatan pengiriman data digital. Data yang dikirimkan sebesar 10 Kbyte dengan kecepatan pengiriman yang divariasikan dari 300 hingga 3600. Terlihat dari Tabel 2 kecepatan pengirimanan data 300 bps hingga pada keceparan 2400 bps tidak mengalami kendala. Saat kecepatan pengiriman datanya ditingkatkan sampai 2600 bps data yang dikirimkan sudah mengalami kesalahan data dan semakin parah saat kecepatan dianikkan. Terliata pada table saat kecepatan mencapai 3600, kecehatan sudah mencapai serratus $100 \%$ dengan tingkat keberhasilan pengiriman pesan $0 \%$.

\begin{tabular}{lllll}
\multicolumn{5}{c}{ TABEL 2. UJI KECEPATAN PENGIRIMAN DATA } \\
\hline No & $\begin{array}{l}\text { Kecepatan } \\
(\mathbf{b p s})\end{array}$ & $\begin{array}{l}\text { Data } \\
(\text { kbyte })\end{array}$ & Kesalahan & $\begin{array}{l}\text { Keberhasilan } \\
(\boldsymbol{\%})\end{array}$ \\
\hline 1. & 300 & 10 & 0 & 100 \\
\hline 2. & 600 & 10 & 0 & 100 \\
\hline 3. & 1200 & 10 & 0 & 100 \\
\hline 3. & 2400 & 10 & 0 & 100 \\
\hline 4. & 2600 & 10 & 8 & 20 \\
\hline 5. & 3200 & 10 & 10 & 0 \\
\hline 6. & 3600 & 10 & 10 & 0 \\
\hline
\end{tabular}

Jaringan ADHOC untuk komunikasi antar kapal membutuhkan perangkat komunikasi yang handal dengan jangkauan pengiriman data yang jauh untuk 
menjamin interkoneksi antar kapal nelayan diarea laut. Komunikasi yang ada saat ini tidak dapat mencakup area laut yang luas sehingga komunikasi antar kapal di area laut lepas tidak memungkinkan dilakukan. Teknologi $A D H O C$ dapat menajadi solusi untuk interkoneksi di area laut lepas. Syarat yang dibutuhkan untuk dapat terjalin interkoneksi kapal nelayan di area laut lepas adalah perangkat komunikasi dengan jangkauan yang jauh.

Kajian dari penelitian ini adalah untuk menggali potensi dari penggunakan komunikasi radio HT sebagai perangkat komunikasi antar kapal nelayan dengan tambahan modulasi data digital dan dikirimkan melalui perangkat audio HT. Beberapa penelitian telah berhasil memanfaatkan HT dan modulator fsk sebagai komunikasi digital. Penelitian ini mengkaji penggunaannya sebagai sarana komunkasi untuk jaringan ADHOC.

Langkah yang dilakukan dalam penelitian ini pertama kali adalah menguji prototipe secara fungsional kemudian melakukan pengujian kecepatan pengiriman data dan pengujian jarak. Dari data tersebut dapat terlihat kemampuan dari prototipe yang dibuat. Terlihat pada data pengujian prototipe yang dibuat telah memenuhi uji fungsional dimana data digital yang dikirimkan dapat sesuai dengan data yang diterima. Uji fungsional ini menunjukkan prototipe siap untuk dilakukan pengujian kecepatan dan jarak untuk mengetahui karakteristik dari prototipe yang dibaut.

Pengujian selanjutnya berupa pengukuran jarak maksimal yang dapat dicapai oleh prototipe perangkat komuniaksi data. Telihat dalam tabel pengukuran jarak bahwa masimal jarak yang dapat digunakan oleh perangkat tersbut adalah $10 \mathrm{~km}$. Jarak ini tentunya adalah jarak masimal dari perangkat komunikasi yang dibuat sehingga untuk mengaplikasikan system tersbut dalam jaringan ADHOC dapat dikalkulasi jarak efektif suatu kapal dengan kapal lain untuk tetap terjalin konektifitas. Peningkatan jarak pengiriman masih memungkinkan untuk ditingkatkan dengan dua acara yaitu dengan mengingkatkan daya pancar dan kedua dengan penggunaan antenna dengan penguatan sinyal yang lebih tinggi.

Pengujian berikutnya dilakukan untuk mengetahui berapa kecepatan pengiriman data maksimal dari prototipe. Pengujian ini dilakukan sebagai informasi yang penting dalam melakukan kalkulasi dan simulasi dari implementasi protocol jaringan $A D H O C$. Kecepatan data maksimal 2400 bps dari prototipe ini memungkinkan untuk komunikasi antar kapal yang baik untuk jenis pertukaran data posisi, informasi perkiraan cuaca, informasi titik tangkapan ikan serta informasi darurat seperti info evakuasi korban di laut.

Informasi posisi kapal berupa data GPS yang terdiri dari koordinat latitude dan longitude menggunakan panjang data byte sebesar 6 byte dengan latitude sebesar 3 byte dan longitude sebesar 3 byte. Dengan kecepatan pengiriman data sebesar 2400 bit per detik atau sekitar 300 byte per ditik maka data posisi setiap kapal dapat dikirimkan sekitar 0,02 detik atau sekitar 50 data posisi kapal dikirimkan setidap detiknya. Informasi peta titik tangkapan ikan yang juga berisi infomasi koordinat gps yang terdiri dari 6 byte data setiap titiknya dapat dikirimkan data sebanyak 50 titik tangkapan ikan setiap detiknya. Prototipe komunikasi data untuk mendukung jaringan ADHOC kapal nelayan sebagai sarana pertukan informasi sangat memungkinkan dilakukan.

\section{SIMPULAN}

Prototipe komunikasi data yang terdiri dari perangkat radio handy talky, sebuah modem fsk yang menggunakan ic TCM3105 dapat mendukung jaringan ADHOC untuk interkoneksi kapal nelayan. Perangkat komunikasi yang dibangun ini dapat digunakan dengan spesifikasi jarak perangkat komunikasi atau jarak antar kapal nelayan tidak lebih dari $10 \mathrm{~km}$. Prototipe komunikasi data yang dibangun berhasil mengirimkan data digital. Perangkat komunikasi data ini memiliki kecepatan pengiriman data maksimal sebesar 2400 bit per detik. Perangkat ini dapat digunakan untuk mengirimkan informasi terkait dengan aktifitas kapal nelayan seperti posisi kapal nelayan, distribusi titik tangkap ikan nelayan dan informasi penting yang lainnya seperti evakuasi kecelakaan laut dan monitoring pelanggaran batas wilayah dari nelayan Indonesia.

\section{DAFTAR PUSTAKA}

[1] M. F. Arianto, "Potensi Wilayah Pesisir di Negara Indonesia," Jurnal Geografi, vol. 10, no. 1, pp. 204-215, 2020.

[2] L. Vinet and A. Zhedanov, "A 'missing' family of classical orthogonal polynomials," JURNAL ELEKTRONIKA TELEKOMUNIKASI DAN COMPUTER, vol. 44, no. 8. pp. 1689-1699, 2011. doi: 10.1088/1751-8113/44/8/085201.

[3] P. I. Puzyrev, M. A. Kvachev, and V. V. Erokhin, "Frequency Shift Chirp Modulation with Additional Differential Phase Shift Keying," International Conference of Young Specialists on Micro/Nanotechnologies and Electron Devices, $E D M$, vol. 2019-June, pp. 78-82, 2019, doi: 10.1109/EDM.2019.8823174. 
[4] R. K. Insanu, H. H. Handayani, and B. M. Sukojo, "Analisis Pemetaan Zona Penangkapan Ikan (Fishing Ground) Dengan Menggunakan Citra Satelit Terra Modis dan Parameter Oseanografi," in Prosiding Seminar Nasional Manajemen Teknologi XVIII,(Murrachman 2006), 2013, pp. 1-13.

[5] N. Berutu, A. Asnidar, and A. Nurman, "Pengaruh Kemampuan Membaca Peta terhadap Penguasaan Konsep Interaksi Keruangan pada Siswa SMA Negeri di Kota Medan," JUPIIS: Jurnal Pendidikan Ilmuilmu Sosial, vol. 5, no. 1, 2013.

[6] S. E. Agusliana M, M. Tadjuddah, and A. Mustafa, "Sebaran suhu permukaan laut dan tracking daerah penangkapan Ikan Cakalang di Perairan Barat Laut Banda," Jurnal Manajemen Sumber Daya Perairan, vol. 2, no. 1, pp. 41-49, 2016.

[7] A. Fuad and A. Affandi, "Mekanisme Komunikasi Data Gateway Multi-Terminal Jaringan Wireless Adhoc Untuk Pengembangan Komunikasi Dan Navigasi Kapal Nelayan," Seminar Nasional Informatika (SEMNASIF), vol. 1, no. 2, pp. 18, 2012. 